\title{
Elektronik Ağızdan Ağıza İletişim Arama ve Sağlama Güdülerinin Türk ve Yabancı Öğrenci Gruplarına Göre Farklılıklarının İncelenmesi
}

\section{Examining Differences between the Motivations of Providing and Seeking Electronic Word-of-Mouth among Turkish and Foreign Student Groups}

\author{
Zehra Bozbay, ${ }^{\mathrm{a}}$ Adem Uysal, ${ }^{\text {,*** }}$ Esra'a Zaid ${ }^{\mathrm{c}}$ \\ ${ }^{a}$ Doç. Dr., İstanbul Üniversitesi, İşletme Fakültesi, Pazarlama Anabilim Dalı, İstanbul/Türkiye. \\ ORCID: 0000-0002-2728-8003
}

bDoktora Öğrencisi, İstanbul Üniversitesi Sosyal Bilimler Enstitüsü, İşletme Fakültesi, Pazarlama Anabilim Dalı, İstanbul/Türkiye. ORCID: 0000-0001-7381-3852

'Doktora Öğrencisi, İstanbul Üniversitesi Sosyal Bilimler Enstitüsü, İşletme Fakültesi, Pazarlama Anabilim Dalı, İstanbul/Türkiye. ORCID: 0000-0001-6800-249X

\section{MAKALE BİLGİSI}

\section{Makale Geçmişi:}

Başvuru tarihi: 10 Ekim 2018

Düzeltme tarihi: 12 Aralık 2018

Kabul tarihi: 23 Ocak 2019

\section{Anahtar Kelimeler:}

Elektronik Ağızdan Ağızda İletişim,

Arama ve Sağlama Güdüleri,

Diskriminant Analizi.

\section{A R T I C LEINFO}

Article history:

Received 10 October 2018

Received in revised form 12 December 2018 Accepted 23 January 2019

\section{Keywords:}

eWOM,

Motivations of Providing and Seeking,

Discriminant Analysis.
ÖZ

Bu çalışmanın amacı tüketicilerin elektronik ağızdan ağıza iletişim (eAAİ) arama ve sağlama güdülerinin ortaya konulması ve bu güdülerin farklı uyruklara mensup öğrenci gruplarına göre değişip değişmediğinin belirlenmesidir. İstanbul'da yaşayan Türk ve yabancı öğrenci gruplarına yönelik olarak bir araştırma yapılmıştır. Çalışmada, eAAİ arama güdülerinin; "sosyal etkileşim faydaları", "risk azaltma", "sosyal yönelimli ürün bilgisi" ve "ürün kullanım bilgileri", eAAİ sağlama güdülerinin ise "kendini geliştirme", "sosyal fayda", ve "olumsuz duyguların ortaya çıkışı" alt boyutlarından oluştuğu saptanmıştır. Çalışmanın bulgularına göre; yabancı öğrenci grupları için arama güdülerinden "sosyal yönelimli ürün bilgisi" faktörünün önemli olduğu, Türk öğrenci grupları için ise arama güdülerinden "risk azaltma", "ürün kullanım bilgileri" ve sağlama güdülerinden "olumsuz duyguların ortaya çıkışı" faktörlerin ayırt edici olduğu yapılan diskriminant analiz sonucunda elde edilmiştir.

\section{A B S T R A C T}

The purpose of this study is to determine the electronic word-of-mouth communication (eWOM) motivations of providing and seeking, and whether these motivations differ among to the groups of students from different nations. A survey was carried out for Turkish and foreign student groups in Istanbul. In the study, eWOM seeking motivations consist of "social interaction benefits", "risk reduction", "social essential product information" and "product usage information", and eWOM providing motivations consist of "self-improvement", "social benefit", and "negative emotions" dimensions. According to the findings of the study; "socially relevant product information" from the eWOM providing motive is important for foreign student groups wheras "risk reduction", "product use information" from the eWOM motivations of providing and "emergence of negative emotions" from the eWOM motivations of seeking are found as discriminators for Turkish student groups.

\section{Giriș}

Günümüzde yüksek bilgi teknoloji sistemlerinin gelişmesi tüketicilerin her yerden internete erişebilmelerini kolaylaştırmaktadır. $\mathrm{Bu}$ ilerleme şüphesiz tüketicilerin birbirleriyle iletişim kurdukları geleneksel yolu değiştirmektedir. Tüketiciler artık internet ağları üzerinden daha fazla iletişim kurma eğilimindedirler. Tüketiciler, ürün/hizmetlerin kullanımı hakkındaki deneyimlerini ve fikirlerini kolayca çevrimiçi olarak paylaşabilmektedirler.

\footnotetext{
** Sorumlu yazar/Corresponding author

e-posta: adem.uysal65@gmail.com
} 
Aynı şekilde, diğer tüketicilerin fikirlerini, ürün/hizmetlerle ilgili değerlendirmelerini görmek adına çevrimiçi olarak arama yapabilmektedirler.

Tanıdıklar, eş-dost arasında ticari olmayan iletişimin sözlü formu olarak tanımlanan geleneksel ağızdan ağıza iletişim (AAI), yeni bir iletişim biçimi olan elektronik ağızdan ağıza iletişim (eAAİ) biçimine dönüşmüştür (Cheung ve Thadani, 2010). eAAİ, internet üzerinden bir ürün/hizmet veya firmaya yönelik fiili, potansiyel ve geçmiş tüketicilerce yapılan herhangi bir olumlu veya olumsuz değerlendirmeyi ifade etmektedir (Henning-Thurau vd., 2004). Tüketiciler, bloglar, ürün inceleme siteleri, satış siteleri ve sosyal ă̆ siteleri aracılığıyla ürün/hizmetler ve markalar ile ilgili yorum ve deneyimlerini paylaşma imkânı bulabilmektedirler (Forman vd., 2008). Tüketiciler eAAİ aracılığıyla deneyimlerini doğrudan başkalarıyla paylaşabilmektedirler (Akehurst, 2009). Thorson ve Rodgers (2006), buna ek olarak, eAAİ'yi tanıdıklar arasında iletişimin farklı seviyelerde çevirimiçi olarak gerçekleşebilmesi şeklinde tanımlamışlardır. Ayrıca, insanlar internet üzerinde bir dizi bilgi kaynağına erişebildikleri için karşılaştırabildikleri bilgilerin genellikle güvenilir olduğunu hissederler (Lerrthaitrakul ve Panjakajornsak, 2014). eAAİ mesajları, bir ürün veya markaya yönelik benzer duyguları paylaşan, küresel kitlelere kolayca ve hızlı bir şekilde ulaşabilir mesajlardır. eAAİ, tüketicilerin birbirleriyle sosyal olarak etkileşimde bulunmalarına, ürünle ilgili bilgileri paylaşmalarına ve bilgisayar aracılığıyla yapılan görüşmeler yoluyla satın alma kararları vermelerine olanak tanımaktadır (Kral vd., 2014).

Tüketicilerin çevrimiçi araştırma yapmasında ve çevrimiçi olarak yorum yazmasında birçok nedenin/güdünün varlığı söz konusudur (Gruen vd., 2006). Tüketicilerin çevrimiçi görüş platformlarında pozitif veya negatif eAAI yaymayı yönlendiren güdülere odaklanan araştırmaların yanı sıra eAAİ arama güdülerini ele alan çalışmalar da mevcuttur. Kwon vd. (2011) çalışmalarında, risk faktörünü minimize etmek, daha kısa sürede bilgi edinmek, ürün kullanım bilgilerine erişebilmek, piyasada yeni ve iyi olan ürünü elde edebilmek, yaşanılabilecek olumsuzlukların önüne geçebilmek, sosyal statü ihtiyacı ve sanal bir topluluğun üyesi olmak gibi güdüleri tüketicilerin eAAİ arama nedenleri olarak siralamaktadırlar. Ayrıca, tüketicilerin çevrimiçi topluluklardaki bilgi kaynaklarını da kendilerini ifade etmede kullandıkları saptanmıştır (Avcılar, 2005). Tüketicilerin elektronik platformlarda yorum yazma davranışlarını etkileyen farklı güdüler de vardır. Bunlar, sosyal ilgi, sosyal yardım, kalite güvencesi, eğlence, kişisel tavır, işlevselselik, ekonomik olarak ödüllenme ve firmalara yardımcı olma şeklindedir ( Hennig-Thurau vd., 2004).

Yukarıda bahsedilen güdülerin yanı sıra, çalışmalar, tüketicilerin ağızdan ağıza iletişım davranışlarına yönelik inanç ve tutumları üzerindeki kültürel etkileri doğrulamışlardır (Lam vd., 2009; Liu vd., 2001). Bu çalışmada, farklı uyrukta tüketicilerin eAAİ ile ilgili davranışlarında ve tutumlarında farklılıklar saptanarak literatüre katkı sunulacağı düşünülmektedir. Özelikle, dünya çapında yorum sitelerinin artması ve bunların tüm tüketiciler tarafından kullanımları göz önünde bulundurulduğunda, eAAİ'nin farklı uyruklara sahip bireylere göre ayrıştırılabilir olup olmadığı sorusunun cevaplanması önemlidir. Bu boşluğu gidermek adına, İstanbul ilinde ikamet eden Türk ve yabancı üniversite öğrenci gruplarına yönelik olarak bir araştırma yapılmıştır. Çalışmanın amacı, eAAİ arama ve sağlama güdülerinin ortaya konulması ve bu güdülerin farklı uyruklara mensup öğrenci gruplarına göre değişip değişmediğinin belirlenmesidir.

\section{Kavramsal Çerçeve}

\subsection{Elektronik Ağızdan Ağıza İletişim (eAAİ)}

Ağızdan ağıza iletişim, sözlü olarak, bir ürün/hizmet hakkında ticari amaç gütmeyen bir alıcı ve iletişimi sağlayan kişiler arasında gelişen kişiler arası iletişim olarak tanımlanmaktadır (Arndt, 1967). Ağızdan ağıza iletişim, ürün ve hizmetlerin değerlendirilmesine ilişkin özel taraflar arasında bilgi iletişimi anlamına da gelmektedir (Anderson, 1998). Pazarlama iletişim araçlarından biri olan ağızdan ağıza iletişim tüketicilerin bir ürün/hizmetten deneyimlerine dayanarak edindikleri olumlu ve olumsuz bilgileri çevresine, arkadaşlarına ve tanıdıklarına aktarması olarak tanımlanmaktadır. Kişilerarası çevrimiçi iletişiminin önemli ve dinamik bir parçası olduğu internet ile birlikte, ağıdan ağıza iletişim (AAİ) farklı bir boyut kazanarak sanal ortama aktarılmıştır (Sun vd., 2006).

Elektronik ağızdan ağıza iletişim (eAAİ), belirli ürün ve hizmetlerin kullanımı veya satıcıların özellikleri ile ilgili internet tabanlı teknolojiler aracılığıyla tüketicilere yönelik resmi olmayan iletişim olarak tanımlanmaktadır (Litvin vd., 2008). Jeong ve Jang'e (2011) göre, geleneksel AAİ'nin aksine, eAAİ birden fazla kişiye yönelik olması, anonim olması ve herhangi bir zamanda erişilebilir olması nedeniyle daha geniş ve hızlı bir şekilde yayılmaktadır. $\mathrm{Bu}$ nedenle, eAAİ'nin tüketicilerin karar verme süreçleri üzerindeki potansiyel etkisi, geleneksel AAİ'in etkisinden daha güçlü olabilmektedir.

Tüketiciler tarafindan ihtiyaç duyulan bilgilerin yayılma ve gerekli bilgilere kolayca sahip olunabilme firsatı sunan internet teknolojileri, sunduğu kolaylıklar sayesinde sanal ortamlarda kişiler arası bilgi aktarımını hızlandırmış ve bilgi aktarımının etkisini artırmıştır (Thevenot ve Watier, 2001). Tüketicilerin eAAİ aracılığıyla fikirlerini sunma ve fikir alışverişinde bulunma biçimleri farklılaşmaktadır. Tüketiciler elektronik ortamlarda ürün/hizmetler hakkındaki görüşlerini, önerilerini veya yorumlarını kolayca yazabilmektedirler. Bu paylaşım, bir web sayfası, çevirimiçi sohbet platformları, bloglar, şirketlerin web siteleri veya çevirimiçi grup tartışma forumları ve sosyal ağ web siteleri üzerinden yapilabilmektedir (Cheung ve Lee, 2008).

Tüketiciler ilgilendikleri ürün ve hizmetlerle ilgili gerekli gördükleri bilgileri sadece arkadaş çevresinden almamaktadırlar. Elektronik ağızdan ağıza iletişim aracılığıyla daha önce hiç karşılaşmadığı, ilişki içerisinde olmadığı kişilerden ürün ve hizmetler ile ilgili gerekli gördükleri bilgileri çevirimiçi iletişim sayesinde elde edebilmektedirler (Henning ve Walsh, 2003). Bu tüketicilerin büyük çoğunluğu bir ürün/hizmet ile ilgili deneyime sahip ve sanal ortamda bunu paylaşmaktan hoşlanan tüketicilerdir. Diğer gruplar ise potansiyel tüketicilerden oluşup, bir ürün/hizmet hakkında bilgi arayışında olanlardır (Sarışık ve Özbay, 2012). Böylelikle, 
her iki tüketici grubunu bir araya getiren sanal ortam, farklı eAAİ arama ve sağlama güdüleri ortaya çıkarmaktadır.

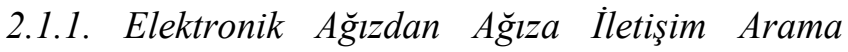 Güdüleri}

İnternet ortamında alışveriş yapmak isteyen tüketicilerin, herhangi bir alışveriş sitesini ziyaret ettiklerinde karşılarına binlerce ürün ve hizmet sunan büyük bir sanal market çıkmaktadır. Çeşitli ürün/hizmetlerin veya markaların olduğu bu ortamda tüketiciler bu ürün/hizmetleri karşılaştırmaları gerekmekte ve tüm bunların arasından bir seçim yapmak zorunda kalabilmektedirler. Tüketiciler bu karmaşık süreci aşmak için ürün ve hizmetler hakkında önceden belirtilmiş yazıları, yorumları araştırarak satın alma davranışlarını gerçekleştirmektedirler. Tüketicileri bu sürece iten farklı eAAİ arama güdüleri söz konusudur.

Hennig-Thurau ve Walsh (2003) çalışmalarında, tüketicilerin zaman tasarrufu sağlamak ve daha iyi bir satın alma gerçekleştirebilmek için çevrimiçi topluluklardaki yorumları dikkate aldıklarını belirtmişlerdir. Tüketiciler satın alırken riskli bir karar almamak veya riski en aza indirmek için eAAİ araştırması yapmaktadırlar (Goldsmith ve Horowitz, 2006).

Ayrıca, yeniliklere ilgi duyan tüketiciler internet ortamındaki yorumları takip ederken; herhangi bir ürün hakkında yaşayabilecekleri problemleri, ürünün kullanma kılavuzunu, yorumlarda elde ettikleri bilgilerle çözmektedirler. Özellikle, teknik destek gerektiren ve karmaşık bir yapıya sahip ürünlerde bu yorumlar önemli bir kaynak olabilmektedir (Godes vd., 2005).

Hennig-Thurau ve Walsh'a (2004) göre ürünün sosyal imajını veya görüntüsünü anlayabilmek ve bir değerlendirme süzgecinden geçirmek için tüketiciler sanal ortamlarda ürünle ilgili paylaşımları okumaktadırlar.

Bununla birlikte, insanlarla iletişim içinde olmayı seven tüketiciler bu konuda çok iyi bir araç olan interneti kullanmaktadırlar (Korgaonkar ve Wolin, 1999). İnternet üzerindeki yorumları diğer insanlarla iletişim kurmak için bir olanak olarak görmektedirler. Böylece, tüketiciler mevcut veya geçmiş satın alma deneyimlerini anlatan tüketicilerin bir parçası olarak bu gruba ait olduklarını hissederler (Hennig- Thurau ve Walsh, 2003).

eAAİ arama güdülerinin tüm çıktıları dikkate alındığında, tüketicilerin ürün/hizmet ile ilgili edindikleri çevrimiçi deneyimler, tüketicilerin satın alma kararlarında maliyetleri en aza indirmelerini ve elde edebilecekleri faydayı en üst düzeyde tutmalarını sağlamaktadır (Aydın, 2014).

\subsubsection{Elektronik Ağıdan Ăğıza İletişim Sağlama Güdüleri}

Tüketiciler, çevrimiçi topluluklarda, sosyal paylaşım sitelerinde, bloglarda, forumlarda bir ürün/hizmet hakkında edindikleri bilgileri, pozitif ve negatif deneyimlerini zaman ve mekân kısıtlamaları olmaksızın tahmin edemeyecekleri sayıda kişilere ulaştırabilmektedirler (Yıldız ve Tehci, 2014). Tüketicileri sanal ortamda söz konusu bilgi paylaşımında bulunduran, yorum yazma davranışına iten farklı güdülerden söz edilebilir (Yıldız, 2016). Bu güdüler farklı çalışmalarda birbirinden farklı sayıda ve boyutlar altında ortaya çıkarılıp belirlenmiştir. Bunlar, tüketicileri düşünme, firmalara yardım etme isteği, bireysel gelişimlerine öncülük etme, ekonomik ve sosyal kazanımlar sunma, firmalara söz geçirebilme, tavsiyeleri dikkate alma, uygun çözüm önerileri sunma, platformların kişi ve firma arasında aracı olma, olumlu ve olumsuz değerlendirmeleri ifade edebilme şeklindedir (Hennig-Thurau vd., 2004; Yildız, 2016; Aydın, 2014).

Örneğin, birçok tüketici ürün/hizmetin kendisine katmış olduğu deneyimleri ve izlenimlerini belirtmekten ve diğer tüketiciler arasında bunların yayılmasından hoşlanmaktadır (Ditcher, 1966). Tüketiciler, deneyim ve izlenimlerini başkalarına verdikleri kararlarda yardımcı olmak ve yaşadıkları olumsuz tecrübelerden onları korumak adına elektronik ortamlarda paylaşmaktadırlar (Engel vd., 1993).

Ayrıca, tüketiciler firmalara yardım etmek maksadıyla internet üzerinde paylaşımlarda bulunmaktadırlar (Shen vd., 2011). Firma ile uzun dönem iliş̧i içinde olan ve firmanın ürünlerine karş1 sadakat düzeyi yüksek olan tüketiciler, firmanın kendisinden başka kişilere ulaşması ve kar oranını artırması amaciyla memnuniyetlerini sanal ortamlarda ifade etmeye çalışırlar (Sundaram vd., 1998).

Tüketiciler sosyal faydaları gözeterek de eAAİ sağlarlar (Hennig-Thurau vd, 2004). Sosyal platformlar, tüketicilerin benzer ilgi alanları, aktiviteleri konusunda birbirleriyle etkileşim içerisinde olmalarına ve sosyalleşmelerine olanak tanımaktadır. Tüketiciler, bloglarda, çevirimiçi toplululuklarda yorum yazarak bir topluma aidiyet hissederler (Hennig-Thurau ve diğerleri, 2004). Tüketiciler, eAAİ sayesinde ürün/hizmetlere yönelik görüş ve düşüncelerini paylaşarak tanımadıkları kişilerle sosyal etkileşim içinde olmaktadırlar (Dellarocas, 2003).

Bununla birlikte tüketiciler ürün/hizmet ya da firmaya ilişkin kararsızlığa düştüklerinde veya özellikle deneyimledikleri olumsuz gelişmeler olduğunda tavsiye aramakta ve başkalarına danışmaktadırlar (Yıldız, 2016). Dolayısıyla, tüketiciler sanal ortamlarda bir ürün/hizmet ya da firma ile ilgili sorunlarla karşılaştıklarında diğer tüketicilere bu sorunları dile getirerek çözüm önerileri beklemektedirler (Hennig-Thurau vd., 2004).

Tüketicilerin sanal platformlarda ürün/hizmet ile ilgili görüşlerini belirtmelerinin bir diğer nedeni ise akıllı bir müşteri olarak kabul edilmek suretiyle kendi öz değerini (saygısını) artırma güdüsüdür (Hennig-Thurau vd. 2004). Böylece, tüketici kendisini duyarlı bir alıcı ve ürün konusunda uzman olarak yansitabilmekte (Aydın, 2014), başkalarının dikkatini çekebilecek, bir konuda söz sahibi olabilecek ve tavsiyede bulunabilecek seviyede olduğunu gösterebilmektedir (Chung \& Darke, 2006).

Ayrıca, internetin gelişmesiyle birlikte, ürün ve hizmetlerin kullanılmasından sonra ortaya çıkan sorunlara ve sıkıntılara maruz kalan tüketiciler, kızgınlıklarını ifade etmek ve hayal kırıklıklarını dile getirmek adına sanal platformları kullanmaktadırlar (Hennig-Thurau vd., 2004). Bilgi alışverişi amacıyla kullanılan bu platformlar, genellikle tüketicilerin deneyimlerini ya da bildiklerini özgürce paylaşabilmelerine ve böylece eAAİ temalarını oluşturmalarına olanak tanımaktadır (Hennig-Thurau vd., 2004). Üçüncü parti olarak ifade edilebilen bu platform sağlayıcıları ise geliştirdikleri yazılımlarla tüketicilerin problemlerini internet ortamında paylaşmalarına imkân tanımaktadır (Tsao, vd. 2015). Ayrıca, platformlarda 
tüketiciler tarafından gerçekleştirilen yorumlar platform yöneticileri tarafından firmalara yönlendirildiği takdirde tüketiciler ürün/hizmet ile ilgili memnuniyetsizliklerini firmalara daha az finansal ve psikolojik maliyetlere katlanarak iletebilme imkânına sahip olmaktadırlar (Aydın, 2014).

Tüketicileri eAAİ sağlamaya iten diğer güdüler ise ekonomik ve sosyal faydaların gözetilmesidir. Sosyal faydalar, eAAİ motivasyonu ile ilgili yapılan ampirik ve teorik çalışmaların çoğunda önemli bir faktör olarak ele alınmıştır (Sridharan, 2016). Tüketicilerin bu aktiviteler içinde yer almasının önemli nedeni başkaları tarafından tanınmak istemek ve başkalarıyla bağlantı kurma firsatı bulmaktır (Yen ve Tang, 2015). Hennig-Thurau vd. (2004), ekonomik kazançları eAAI davranışlarının gerçekleşmesinde önemli bir faktör olarak sıralamaktadırlar. Tüketiciler yorumlarıyla sitenin bilinirliğini arttırmakta, kuponlar, puanlar ve parasal ödüller gibi ekonomik faydalar elde edebilmektedirler.

\section{Yöntem}

$\mathrm{Bu}$ çalışmanın temel amacı internet kullanıcılarının eAAI arama ve sağlama güdülerine ait alt boyutlarını ortaya koymak, eAAİ arama ve sağlama güdülerinin farklı uyruklara mensup öğrenci gruplarına göre farklılık gösterip göstermediğini araştırmaktır.

Araştırmanın kapsamını internet üzerinde herhangi bir ürün/hizmet satın alan, yorum araştıran, bununla birlikte ürün/hizmetler hakkında olumlu veya olumsuz düşünce ve deneyimlerini diğer tüketicilere aktaran öğrenciler oluşturmaktadır. Bu doğrultuda, araştırma İstanbul ilinde bulunan Türk ve yabancı üniversite öğrenci gruplarına uygulanmıştır. Özellikle üniversite öğrencilerinin yoğun bir şekilde internet kullanmaları çeşitli teknolojik araçlarla internete daha rahat erişim sağlamaları ve internetten maksimum düzeyde yararlanmaları bu çalışmada üniversite öğrencilerinin hedef kitle olarak belirlenmesinde etkili olmuştur (Balcı ve Ayhan, 2007).

Araştırmanın ana kütlesini İstanbul ilinde ikamet eden, internet ortamından herhangi bir ürün ve hizmet için eAAI arayan ve sağlayan öğrenciler oluşturmaktadır.
eAAİ arama ve sağlama güdülerini ölçmek üzere Han (2008) ve Aydın (2014) çalışmalarından yararlanılmıştır. Araştırmanın hipotezleri aşağıdaki gibidir.

H1: Türk ve yabancı öğrenci grupları birbirlerinden eAAİ arama güdüleri itibariyle ayrışır.

H2: Türk ve yabancı öğrenci grupları birbirlerinden eAAİ sağlama güdüleri itibariyle ayrışır.

Veri toplama sürecine geçmeden önce sorulara son şeklini vermek ve yanlış anlamaları azaltmak için anket formu 30 kişilik bir öğrenci grubu ile ön teste tabi tutulmuştur. Sonuçlara göre anket soruları yeniden düzenlenerek anket formuna son şekli verilmiştir.

Yüz yüze anket yönteminin kullanıldı̆̆ı çalışmada 380 anket doldurulmuştur. Tam olarak tamamlanmamış ve tutarsız cevaplar içeren 40 anket değerlendirmeye alınmamış, 340 anket analiz sürecine dahil edilmiştir.

Araştırmaya katılan tüketicilerin sosyo-demografik özelliklerine, yerli ve yabancı öğrenci grubu sayısına ve gelir düzeyine ilişkin tanımlayıcı istatistikler Tablo 1'de yer almaktadır. Öğrenci grupları bakımından cevaplayıcıların $\% 50$ 'sinin yabanc1 ve \%50'sinin Türk olduğu belirlenmiştir. Çalışmada verilerin karşılaştırılması amacıyla eşit sayıda öğrenci grupları analize dahil edilmiştir. Cevaplayıcıların yaşları incelendiğinde Türk ve yabancı öğrenci gruplarının çoğunlukla 25 yaş ve altında olduğu, her iki grupta k1z ve erkek öğrencilerinin sayılarının dengeli dağıldığı görülmektedir. Aylık gelirleri açısından Türk öğrenci gruplarının çoğunluğunun $(\% 48,2)$ 250-500 TL aylık gelire sahip oldukları gözlemlenirken, yabancı öğrenci grublarındaki katılımcıların çoğunluğunun aylık gelirlerinin 501TL ve $1000 \mathrm{TL}$ aralığında olduğu görülmektedir. Her iki gruptaki katılımcıların büyük çoğunluğu $(\% 35,3)$ internet üzerinden yıllık olarak alışveriş yaptıklarını belirtmişlerdir. Bununla birlikte her iki grupta katılımcıların çoğunluğunun altı ay içerisinde internet üzerinden satın aldıkları ürün tutarının 200 TL'den az olduğu görülmektedir.

Tablo 1. Cevaplayıcıların Sosyo-Demografik Özellikleri

\begin{tabular}{|c|c|c|c|c|}
\hline & Türk Öğrenci Grupları: & 170 Öğrenci & Yabancı Öğrenci Grupları: & 170 Öğrenci \\
\hline Yaş & Frekans & Yüzde & Frekans & Yüzde \\
\hline 18 alt1 & 26 & 15,3 & 8 & 4,7 \\
\hline $18-21$ aras1 & 48 & 28,2 & 54 & 31,8 \\
\hline $22-25$ aras 1 & 57 & 33,5 & 58 & 34,1 \\
\hline $26-29$ aras1 & 17 & 10,0 & 33 & 19,4 \\
\hline 29 ve üzeri & 22 & 12,9 & 17 & 10,0 \\
\hline Cinsiyet & Frekans & Yüzde & & \\
\hline Kadın & 84 & 49,4 & 82 & 48,2 \\
\hline Erkek & 86 & 50,6 & 88 & 51,8 \\
\hline Aylık Gelir & Frekans & Yüzde & Frekans & Yüzde \\
\hline $250-500 \mathrm{TL}$ & 82 & 48,2 & 26 & 15,3 \\
\hline $501-750 \mathrm{TL}$ & 28 & 16,5 & 54 & 31,8 \\
\hline $751-1000 \mathrm{TL}$ & 23 & 13,5 & 54 & 31,8 \\
\hline 1001TL ve üzeri & 37 & 21,8 & 36 & 21,2 \\
\hline $\begin{array}{l}\text { Internette Alışveriş } \\
\text { Yapma Sıklığı }\end{array}$ & & & & \\
\hline
\end{tabular}




\begin{tabular}{|c|c|c|c|c|}
\hline Alışveriş yapmıyorum & Frekans & Yüzde & Frekans & Yüzde \\
\hline Günlük & 30 & 17,6 & 41 & 24,1 \\
\hline Haftalık & 3 & 1,8 & 10 & 5,9 \\
\hline Aylik & 21 & 12,4 & 12 & 7,1 \\
\hline Y1llik & 60 & 35,3 & 60 & 35,3 \\
\hline $\begin{array}{l}\text { Son } 6 \text { ay İnternet } \\
\text { Alışveriş Miktarı }\end{array}$ & Frekans & Yüzde & Frekans & Yüzde \\
\hline $200 \mathrm{TL}$ den az & 97 & 57,1 & 88 & 51,8 \\
\hline $201-400 \mathrm{TL}$ & 28 & 16,5 & 35 & 20,6 \\
\hline $401-600 \mathrm{TL}$ & 18 & 10,6 & 11 & 6,5 \\
\hline $601-1000 \mathrm{TL}$ & 8 & 4,7 & 20 & 11,8 \\
\hline $1001-1500 \mathrm{TL}$ & 4 & 2,4 & 12 & 7,1 \\
\hline 1501 TL ve üzeri & 15 & 8,8 & 4 & 2,4 \\
\hline
\end{tabular}

\section{Analiz ve Bulgular}

4.1. eAAİ Arama ve Sağlama Güdülerinin Faktör Yapılarının Belirlenmesi

eAAİ arama güdülerinin faktör yapısını incelemek için keşfedici faktör analizi uygulanmıştır. Faktör analizine geçmeden önce veri seti içinde aykırı değer olup olmadığını belirlemek için veri noktaları $\mathrm{Z}$ puanına dönüștürülerek yüksek değer görüntülenebilir (Koğar, 2010). Buna göre, veri setinde üç aykırı değer olduğu tespit edilmiş ve bu değerler analizden çıkartılmıştır. Ayrıca, eAAİ arama güdülerine ait bütün maddelerin normal dağllp dağılmadığııı ölçmek için maddelerin basıklık ve çarpıklık değerlerine bakılmış, maddelerin normal dağıldı ̆̆ görülmüştür.

Araştırma ölçeklerinin yap1 geçerliğinin incelenmesi amaciyla eAAI arama güdülerinin faktör yapısını belirleyebilmek için keşfedici faktör analizi uygulanmıștır. Kaiser-Meyer-Olkin (KMO) ve Barlett Küresellik Testleri ile verilerin faktör analizine uygun olup olmadığ 1 açıklanmıștır. Ölçeğe ait faktörleri belirlemek için temel bileşenler analizi ve Varimax döndürme metodu uygulanmıştır (Hair vd., 2010). Ölçümlerin güvenilir olup olmadığını değerlendirmek amacıyla her ölçeğe Cronbach Alfa analizi uygulanmıştır. Keşfedici faktör analizinde faktör yüklerinin kesme noktası 0.40 olarak belirlenmiş, bu değerin altında kalan herhangi bir maddenin olmadığ 1 gözlemlenmiştir. Ancak, bir madde binişik olması ve diğer bir maddenin yükleme yapılan boyut ile uyumunun zayıf olması sebebiyle iki madde faktör analizinden kademeli olarak çıkarılmıştır.

Yapılan keşfedici faktör analizleri sonucunda elde edilen nihai faktör yapıları, faktör yükleri, faktörlerin açıklama oranları ve güvenilirlik analizi sonuçları Tablo 2'de yer almaktadır.

Tablo 2 eAAİ Arama Güdüleri Ölçeğine İlişkin Güvenilirlik ve Geçerlilik Analizi

\begin{tabular}{|c|c|c|c|}
\hline BOYUTLAR (FAKTÖRLER) & $\begin{array}{l}\text { Faktör } \\
\text { Yükleri }\end{array}$ & $\begin{array}{l}\text { Cronbach's } \\
\text { Alfa }\end{array}$ & $\begin{array}{c}\text { Açıklanan } \\
\text { Varyans (\%) }\end{array}$ \\
\hline Sosyal Etkileşim Faydaları & & ,862 & 37,890 \\
\hline Çünkü, diğer insanlarla iletişim kurmak eğlencelidir. & ,811 & & \\
\hline Çünkü bir gruba ait olduğumu hissedderim. & ,807 & & \\
\hline Çünkü, insanlarla iletişim içinde olmayı severim. & ,781 & & \\
\hline Böylece, bir topluluğun parçası olmaktan gerçekten mutluluk duyarım & ,751 & & \\
\hline Böylece, paylaşımda bulunan ilgi alanları benzer olan birçok kişiyle iletişim kurarım & ,740 & & \\
\hline Risk Azaltma & & ,785 & 14,688 \\
\hline Aldığım karardan dolayı pişman olmak istemiyorum & ,771 & & \\
\hline Riskli bir karar almaktan kaçınırım & ,759 & & \\
\hline Kötü bir ürün almak istemiyorum & ,712 & & \\
\hline Kötü bir ürün satın alma olasılığım azalır. & ,729 & & \\
\hline Sosyal Yönelimli Ürün Bilgisi & & ,822 & 7,441 \\
\hline Ürünün sosyal imajını, görüntüsünü anlayabilirim & ,647 & & \\
\hline Hangi konuların "popüler" olduğundan haberdar olurum & ,772 & & \\
\hline Ürünün popüler olup olmadığını bilebilirim & ,820 & & \\
\hline Yeni olan şeylere ilgi duyarım & ,772 & & \\
\hline Ürün Kullanım Bilgileri & & ,720 & 5,560 \\
\hline Endişelerimle ilgili uzmanların görüşünü alırım. & ,710 & & \\
\hline Ürünle ilgili bir sorunum olduğunda tavsiye ve çözüm bulurum & ,646 & & \\
\hline $\begin{array}{l}\text { Çünkü ürünle ilgili sıkıntılarla karşılaştığımda, internet ortamında yazılan yorumları } \\
\text { okuyarak doğru cevapları bulurum. }\end{array}$ & ,713 & & \\
\hline
\end{tabular}

\section{Açıklanan Toplam Varyans: 65,57\%; Cronbach's Alfa: 0,895}

Faktör analizi neticesinde ortaya çıkan dört faktör sosyal etkileşim faydaları, risk azaltma, sosyal yönelimli ürün bilgisi ve ürün kullanım bilgileri olarak isimlendirilmiştir.
Faktör sayısı itibariyle çalışma Han'ın (2008) çalışmasıyla örtüșmektedir. 
Keşfedici faktör analizi sonucunda elde edilen her bir ölçek yapısı itibariyle ölçeklerin güvenilirliğine yönelik Cronbach's Alfa değerleri elde edilmiştir. Buna göre her bir ölçek yapısının Cronbach's Alfa değerlerinin 0,70’ten büyük olduğu saptanmış ve ölçek yapılarına ilişkin ölçümlerin yüksek düzeyde güvenilir olduğu değerlendirilmiştir (Kurtuluş, 2010).

\section{2 eAAİ Sağlama Güdülerinin Faktör Yapılarının Belirlenmesi}

eAAİ sağlama güdülerine ait 15 maddeden oluşan ölçeğe ait Kaiser-Meyer-Olkin (KMO) ve Barlett Küresellik Testleri ile verilerin faktör analizine uygun olup olmadığı açıklanmıştır. Ölçeğe ait faktörleri belirlemek için temel bileşenler analizi ve Varimax döndürme metodu uygulanmıştır (Hair vd., 2010). Alt kesme noktası 0.40 olarak belirlenen faktör yük değerinin altında herhangi bir

Tablo 3 eAAİ Sağlama Güdüleri Ölçeğine İlişkin Güvenilirlik ve Geçerlilik Analizi

\begin{tabular}{|c|c|c|c|}
\hline BOYUTLAR (FAKTÖRLER) & $\begin{array}{l}\text { Faktör } \\
\text { Yükleri }\end{array}$ & $\begin{array}{l}\text { Cronbach's } \\
\text { Alfa }\end{array}$ & $\begin{array}{l}\text { Açılanan } \\
\text { Varyans(\%) }\end{array}$ \\
\hline Kendini Geliştirme & & ,924 & 48,301 \\
\hline Yaşadığım olumlu deneyimlerle diğerlerine yardım etmek isterim. & ,816 & & \\
\hline $\mathrm{Bu}$ yolla, iyi bir alışveriş hakkında kendi memnuniyetimi başkalarına ifade ederim & ,818 & & \\
\hline Başarılı deneyimlerimi diğerlerine aktarıım. & ,769 & & \\
\hline Yaşadığım kötü deneyimler hususunda diğerlerini uyarmak isterim &, 850 & & \\
\hline Yaşadığım kötü deneyimlerden diğerlerini korumak isterim. & ,845 & & \\
\hline Başarılı deneyimlerimi diğerlerine ifade ettiğim zaman kendimi iyi hissederim & 687 & & \\
\hline Sosyal Fayda & & ,846 & 11,397 \\
\hline Bu yolla hoş insanlarla tanışırım & ,865 & & \\
\hline Aynı düşünen insanlar arasında sohbetin güzel olduğuna inanırım &, 821 & & \\
\hline $\begin{array}{l}\text { Toplum içindeki diğer insanlarla bu şekilde iletişim kurmanın eğlenceli olduğunu } \\
\text { düşünürüm. }\end{array}$ & ,786 & & \\
\hline Diğerleri ile birlikte olmak düşüncesi beni güçlü kılar. & 675 & & \\
\hline Olumsuz Duyguların Ortaya Çıkışı & & ,731 & 8,324 \\
\hline $\begin{array}{l}\text { Sosyal platformlarda bir ürün veya hizmet hakkında bilgi alış verişi yapmak, diğer } \\
\text { yöntemlere göre daha uygundur }\end{array}$ & ,781 & & \\
\hline Problem yaşadığım kuruluşa, bende zarar vermek isterim & ,769 & & \\
\hline Yaşadığım problemlerin çözümünde, ilgili kuruluşun daha fazla yardımcı olmasını sağlar & 582 & & \\
\hline Ürün ya da hizmete ait bir problem hakkında konuşmaktan hoşlanırım & ,512 & & \\
\hline
\end{tabular}

\section{3. eAAİ Arama ve Sağlama Güdülerinin Öğrenci Gruplarına Göre Analizi}

Çalışmanın amacı doğrultusunda, eAAİ arama ve sağlama güdülerinin Türk ve yabancı öğrenci gruplarına göre farklılık gösterip göstermediğini belirlemek için diskriminant analizinden faydalanılmıştır.

Diskriminant analizi bireyleri gruplara ayırmak için kullanılan bağımsız değişkenlere dayalı bir dizi tahmin denklemini (fonksiyonunu) belirlemektedir. Bir diskriminant analizinde iki olası hedef vardır. Bunlar, yeni bireyleri sınıflandırmak için bir tahmin denklemini oluşturmak ve değişkenler arasında var olabilecek ilişkileri daha iyi anlamak için tahmin denklemini yorumlamaktır (Savić, vd. 2008)

Analize geçmeden önce, diskriminant analizi için gerekli varsayımlardan biri olan değişkenlerin normal dağıldığı varsayımı sağlanmıştır. Diğer bir varsayım olan çoklu bağlantı için değişkenler arasındaki ilişkileri gösteren korelasyonlara bakılmış ve çoklu doğrusal bağlantı durumu maddenin olmadığ 1 gözlemlenmiştir. Ancak bir madde birden fazla faktöre 0.10 'dan daha az düzeyde yüklendiğinden çıkarılmıştır.

Yapılan keşfedici faktör analizleri sonucunda elde edilen nihai faktör yapıları, faktör yükleri, faktörlerin açıklama oranları ve güvenilirlik analizi sonuçları Tablo 3 'te yer almaktadır. Faktör analizi neticesinde ortaya çıkan üç faktör kendini geliştirme, sosyal fayda ve olumsuz duyguların ortaya çıkışı olarak isimlendirilmiştir. Keşfedici faktör analizi sonucunda elde edilen her bir ölçek yapısı itibariyle ölçeklerin güvenilirliklerine yönelik Cronbach's Alfa değerleri elde edilmiştir. Buna göre her bir ölçek yapısının Cronbach's Alfa değerlerinin 0,70'ten büyük olduğu saptanmış ve ölçek yapılarına ilişkin ölçümlerin yüksek düzeyde güvenilir olduğu değerlendirilmiştir (Kurtuluş, 2010). 


\begin{tabular}{lllll}
86,827 & 3,033 & 28 & 398091,615 &, 000 \\
\hline
\end{tabular}

Bağımsız değişkenin iki grup ortalama farklarının istatistiksel anlamlılığını ölçmek için Wilk’s Lambda ve ANOVA testi kullanılmıştır (Yalman, vd. 2012). Aşamalı diskriminant analizi yöntemi kullanılarak test edilen modelde kanonik diskriminant fonksiyonu incelendiğinde
0.05 önem derecesinde diskriminant fonksiyonunun eAA arama güdülerinden "risk azaltma", "sosyal yönelimli ürün bilgisi" ve "ürün kullanım bilgileri" boyutlarının; bununla birlikte eAAİ sağlama güdülerinden "olumsuz duyguların ortaya çıkışı" boyutunun anlamlı olduğu görülmüştür (Bkz. Tablo 5).

Tablo 5. Grup Ortalamalarının Eşitlik Testi

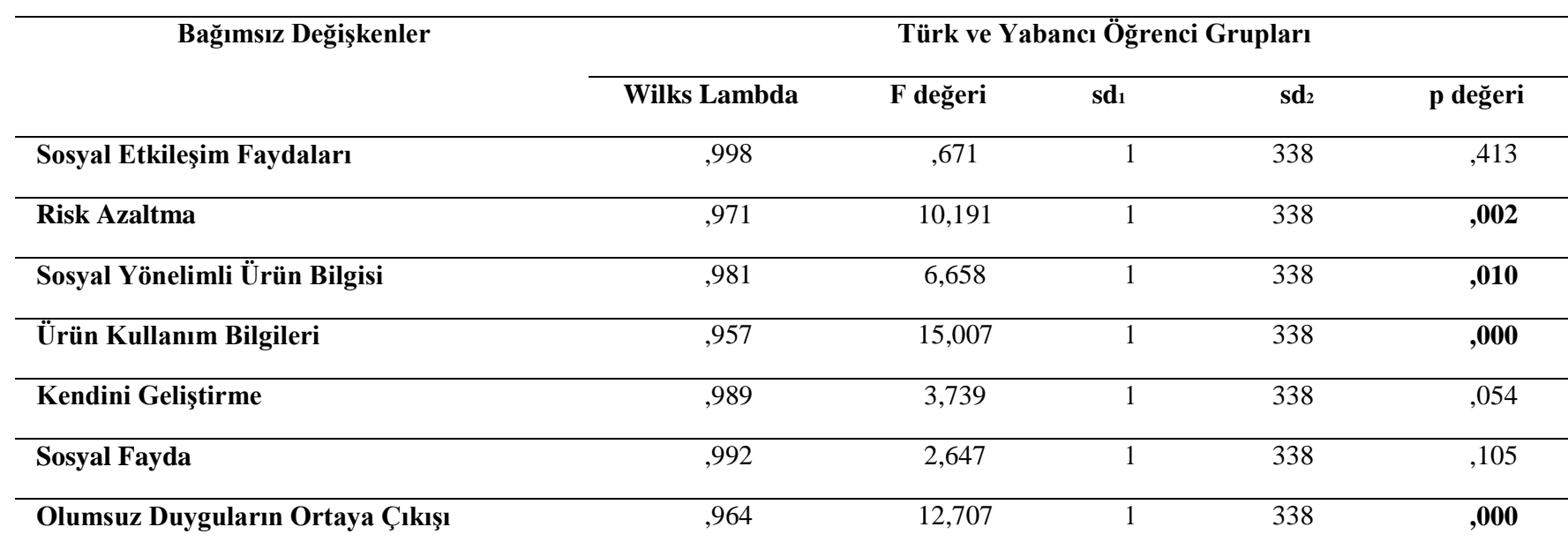

Kullanılan aşamalı diskriminant analizi sonuçlarına bakıldığında, modele yalnızca "risk azaltma", "sosyal yönelimli ürün bilgisi", "ürün kullanım bilgileri" ve "olumsuz duyguların ortaya çıkışı" faktörlerinin alınması gerektiği ve diğer değişkenlerin analiz dışında tutulması gerektiği görülmektedir. $\mathrm{Bu}$ faktör yapısını kullanarak diskriminant analizi yenilenmiştir. Dolayısıyla, faktörlere ilişkin diskriminant fonksiyonu standart kanonik diskriminant fonksiyon katsayıları dikkate alınarak; $\mathrm{F}(\mathrm{y})=$ 0,239 risk azaltma $-0,99$ sosyal yönelimli ürün bilgisi $+0,551$ ürün kullanım bilgileri $+0,515$ olumsuz duyguların ortaya çıkışı şeklinde belirlenmiştir.

Tablo 6. Kanonik (Kümelerarası) Diskriminant Fonksiyonu

\begin{tabular}{cccc}
\hline Özdeğer & \% Varyans & \% Kümülatif & Kanonik \\
\hline$, 0,61^{\mathrm{a}}$ & 100,0 & 100,0 &, 239 \\
\hline $\begin{array}{c}\text { Wilk's } \\
\text { Lambda }\end{array}$ & Ki kare & sd & $\begin{array}{c}\mathbf{p} \\
\text { değeri }\end{array}$ \\
\hline, 943 & 19,664 & 4 & 0,001 \\
\hline
\end{tabular}

Ayırma fonksiyonunun önemini belirlemek için özdeğer (eigenvalue), Wilk's Lambda ve kanonik korelasyon değerlerine bakılır. Özdeğer, bağlı değişkendeki varyansın fonksiyonların her biri tarafindan ne kadarlık bir bölümünün açıklanabileceğini göstermektedir (Oğuzlar, 2006). Kanonik korelasyonun karesi ise modelin bağımlı değişkendeki değişimini açıklamaktadır. Tablo 6'da yer alan kanonik korelasyon katsayısı incelendiğinde gruplar arası farklılıkların yaklaşık olarak \% 6'sını açıklayabildiği görülmektedir.

Ayırma fonksiyonunun önemini gösteren bir diğer değer Wilks' Lambda değeridir. Wilks' Lambda, modelde diskriminant fonksiyonunun etkinliğini ölçer. Wilk's Lambda değeri, bağımlı değişkenlerdeki değişkenliğin yüzde kaçının bağımsız değişkenler tarafından açıklandığını gösterir. Fonksiyonun anlamlığınının test edilmesi Wilk's Lambda'nın diğer bir işlevidir. Burada 0,943 değeri, Wilk's Lambda'nın önemli bir değere sahip olduğunu $(p=0,000)$ yani, grupların farklılaşabileceğini göstermektedir (Brown ve Wicker, 2000). Ancak, hangi bileşenlerin ayrıştığını görebilmek için standardize edilmiş ayırma fonksiyonunu daha sonra bunu indirgeyen yapısal matrisin elde edilmesi gereklidir.

Tablo 7. Kanonik (Kümelerarası) Diskriminant Fonksiyonu Standart Katsayıları ve Yap1 Matrisi

\begin{tabular}{lcc}
\hline \multicolumn{1}{c}{$\begin{array}{c}\text { Standart Kanonimsı } \\
\text { Değişkenler }\end{array}$} & $\begin{array}{c}\text { Fonksiminant } \\
\text { Konks } \\
\text { Katsayıları }\end{array}$ & Yapı Matrisi \\
\hline Risk Azaltma &, 239 &, 705 \\
\hline $\begin{array}{l}\text { Sosyal Yönelimli } \\
\text { Ürün Bilgisi }\end{array}$ & $-0,99$ &, 570 \\
\hline Ürün Kullanım &, 551 &, 856 \\
Bilgileri & & \\
\hline Olumsuz & & \\
Duyguların &, 515 &, 788 \\
Ortaya Çıkışı &
\end{tabular}

Tablo 7'de bağımsız değişkenlerin standart ve standart olmayan katsayıları ve yapı matrisleri yer almaktadır. Standart katsayıları model içinde yer alan değişkenlerin fonksiyona katkılarına yönelik karşılaştırma yapılırken kullanılmaktadır (Yalman vd. 2012) Standart katsayılara bakıldığında, diskriminant fonksiyonuna katkısı en çok olan boyutların "ürün kullanım bilgileri" ve "olumsuz duyguların ortaya çıkışı" olduğu görülmektedir (sırasıyla 0,856 ve 0,788). Diğer önemli boyutlar ise "risk azaltma" ve "sosyal yönelimli ürün bilgisi" boyutlarıdır.

Yap1 matrisinde görüldüğü gibi fonksiyona en önemli katkıyı "ürün kullanım bilgileri" ve "olumsuz duyguların ortaya çıkışı" değişkenleri yapmıştır. En az katkı yapan değişken ise "sosyal yönelimli ürün bilgisi" değişkenidir (0,99).

Tablo 8. Sinıflandirma Fonksiyonu Katsayıları (Fisher'in Doğrusal Diskriminant Fonksiyonu) 


\begin{tabular}{llc}
\hline Bağımsız Değişkenler & \multicolumn{2}{c}{$\begin{array}{c}\text { Türk ve Yabancı Öğrenci } \\
\text { Grupları }\end{array}$} \\
\hline & Yabancı & Türk \\
\hline Risk Azaltma & 3,355 & $\mathbf{3 , 5 0 8}$ \\
\hline $\begin{array}{l}\text { Sosyal Yönelimli Ürün } \\
\text { Bilgisi }\end{array}$ & $\mathbf{1 , 0 1 0}$ &, 954 \\
\hline Ürün Kullanım Bilgileri & 1,899 & $\mathbf{2 , 2 3 8}$ \\
\hline $\begin{array}{l}\text { Olumsuz Duyguların Ortaya } \\
\text { Çıkış1 }\end{array}$ & 2,174 & $\mathbf{2 , 4 8 1}$ \\
\hline Sabit & & \\
\hline
\end{tabular}

Sınıflandırma fonksiyonu incelendiğinde yabancı öğrenci grupları için "sosyal yönelimli ürün bilgisi" ve "sosyal fayda" boyutlarının önemli olduğu, Türk öğrenci grupları için ise "olumsuz duyguların ortaya çıkıșı", "risk azaltma" ve "ürün kullanım bilgileri" boyutlarının ayırt edici olduğu yapılan diskriminant analiz sonucunda elde edilmiştir.

Diskriminant fonksiyonunun anlamlılığının test edilmesi grup ortalamalarının birbirinden uzaklıklarına dayanmaktadır. Dağılımlar birbirinden uzaklaştıkça diskriminant fonksiyonunun ayrıştırma özelliği artmaktadır (Yalman vd., 2012). Tablo 9'da görüldüğü gibi modelde yer alan yabancı öğrenci grubunun eAAİ arama ve sağlama güdüleri için oluşturulan diskriminant fonksiyonuna ait grup ortalaması -,245 iken Türk öğrenci grubuna göre oluşturulan diskriminant fonksiyonuna ait grup ortalaması 0,245 olarak hesaplanmıştır.

Tablo 9. Kanonik Diskriminant Fonksiyonu Grup Ortalamaları

\begin{tabular}{cc}
\hline Öğrenci Grupları & Grup Ortalaması \\
\hline Yabancı Öğrenci Grubu &,- 245 \\
\hline Türk Öğrenci Grubu &, 245 \\
\hline
\end{tabular}

Modelde elde edilen diskriminant fonksiyonu kullanılarak gözlemler sınıflandırıldığında 340 kişilik öğrenci grubundan oluşan kontrol grubunun doğru sınıflandırma oranı \% 58,8, uygulama grubunda elde edilen doğru sınıflandırma oranı ise \% 61,2 olarak bulunmuştur.

Tablo 10. Sınıflandırma Sonuçları

\begin{tabular}{|c|c|c|c|c|}
\hline \multirow[t]{2}{*}{ Uygulama Grubu } & \multirow[t]{2}{*}{ Gerçek Grup Üyeliği } & \multicolumn{3}{|c|}{ Tahmin Edilen Grup Üyeliği } \\
\hline & & Yabancl & Türk & Toplam \\
\hline \multirow{4}{*}{ Doğru sınıflandırma oranı: \% 61,2 } & \multirow[t]{2}{*}{ Yabancl } & 100 & 70 & 170 \\
\hline & & $\% 58,8$ & $\% 41,2$ & $\% 100,0$ \\
\hline & \multirow[t]{2}{*}{ Türk } & 62 & 108 & 170 \\
\hline & & $\% 36,5$ & $\% 63,5$ & $\% 100,0$ \\
\hline \multirow[t]{2}{*}{ Kontrol Grubu } & \multirow[t]{2}{*}{ Gerçek Grup Üyeliği } & \multicolumn{3}{|c|}{ Tahmin Edilen Grup Üyeliği } \\
\hline & & Yabancl & Türk & Toplam \\
\hline \multirow{4}{*}{ Doğru sınıflandırma oranı: $\% 58,8$} & \multirow[t]{2}{*}{ Yabancl } & 95 & 75 & 170 \\
\hline & & $\% 55,9$ & $\% 44,1$ & $\% 100,0$ \\
\hline & \multirow[t]{2}{*}{ Türk } & 65 & 105 & 170 \\
\hline & & $\% 38,2$ & $\% 61,8$ & $\% 100,0$ \\
\hline
\end{tabular}

\section{Sonuç ve Öneriler}

$\mathrm{Bu}$ çalıșmanın amacı, tüketicilerin internet ortamında herhangi bir ürün/hizmet veya markayla ilgili elektronik ağızdan ağıza iletişim (eAAİ) arama ve sağlama güdülerini oluşturan faktörleri belirlemek ve bu faktörlerin Türk ve yabancı öğrenci gruplarına göre farklılıklarını ortaya koymaktır.

Tüketiciler, satın alma karar sürecinin ilk aşaması olan ihtiyaçlarını belirledikten sonra, ikinci aşama olarak ürün/hizmetin değerlendirmesine yönelik bilgiye ihtiyaç duymaktadırlar. $\mathrm{Bu}$ bağlamda, diğer tüketicilerin ürün/hizmete dair deneyimleri ve izlenimleri bilgi ihtiyaçlarının karşılanmasında önemli bir işlev görmektedir. Tüketiciler eAAİ arama ile sadece bilgi ihtiyaçlarını karşılamakla kalmayıp, eAAİ de sağlayarak, sanal ortamda deneyimlerini başkalarıyla paylaşma imkânına sahip olmaktadırlar.

Çalışmanın amacı doğrultusunda, araştırma İstanbul ilinde bulunan Türk ve yabancı üniversite öğrenci gruplarına uygulanmıştır. Çalışmada, eAAİ arama ve sağlama güdülerine ait ifadelere yönelik faktör yapılarını belirlemek için faktör analizi uygulanmıştır. Analiz neticesinde, eAAI arama güdüleri sosyal etkileşim faydaları, risk azaltma, sosyal yönelimli ürün bilgisi ve ürün kullanım bilgileri alt boyutlarından oluştuğu bulunmuştur. Ayrıca, katılımcıları eAAİ sağlamaya motive eden faktörleri belirmeye yönelik olarak yapılan faktör analizi sonucunda kendini geliştirme, sosyal fayda ve olumsuz duyguların ortaya çıkışı olarak üç temel boyut ortaya çıkmıştır.

Çalışmada, Türk ve yabancı öğrenci gruplarının birbirlerinden hangi eAAİ arama ve sağlama güdüleri itibariyle ayrıştığı belirlenmiştir. Çalışmanın bulgularına göre; yabanc1 öğrenci grupları için eAAI arama güdülerinden "sosyal yönelimli ürün bilgisi" boyutunun önemli olduğu, Türk öğrenci grupları için ise; eAAİ arama güdülerinden "risk azaltma", "ürün kullanım bilgileri" ve eAAİ sağlama güdülerinden "olumsuz duyguların ortaya çıkışı" boyutlarının ayırt edici olduğu bulunmuştur.

Analiz sonuçlarına göre eAAİ arama güdülerinden dört boyuttan üçünün öğrenci gruplarına göre anlamlı olarak farklılaştığı görülmektedir. "Sosyal yönelimli ürün bilgisi" boyutu itibariyle yabancı öğrenci grubunun Türk öğrenci grubuna göre anlamlı şekilde farklılaştıkları tespit edilmiştir. Öğrenci gruplarına göre farklılaşan diğer iki boyut ise "ürün kullanım bilgisi" ve "risk azaltma" boyutlarıdır. Analiz sonuçları eAAİ arama güdülerinden "sosyal etkileşim faydaları" boyutunun öğrenci gruplarına göre farklılaşmadığını ortaya koymuştur. Ayrıca, eAAİ sağlama güdülerinin oluştuğu üç boyuttan sadece "olumsuz duyguların ortaya çıkışı" boyutunun öğrenci gruplarına göre anlamlı olarak farklılaştığı görülmektedir. Çalışmanın bulgularına göre, yabancı öğrenci grupları için "sosyal etkileşim faydaları" ve "sosyal fayda" faktörleri eAAI arama ve sağlama nedenleri olarak tanımlanmaktadır. Böylece, eAAİ ile bağlantılı bu grupların, insanlarla iletişim 
kurmak, aidiyet duygusu, toplumsallaşma ve sosyalleşme amacıyla çevrimiçi topluluklara katıldıkları görülmektedir. Türk öğrenci grupları için ise "risk azaltma","ürün kullanım bilgileri" ve "olumsuz duyguların ortaya çıkışı" boyutlarının internette bir ürün/hizmet ile ilgili yorum okuma ve yazma davranışlarının şekillenmesinde başlıca güdüler oldukları görülmektedir. Yani, bu grubu oluşturan katılımcıların, firmaya yönelik memnuniyetsizliklerini ifade etmek, diğer tüketiciler nezdinde bir imaj oluşturmak, ürünü daha iyi anlamak, kullanmak ve riskli bir satın alma kararı vermemek adına çevirimiçi oldukları görülmektedir. $\mathrm{Bu}$ bulguların, bir ürün/hizmet ile ilgili sanal ortamdaki yorumların farklı tüketici grupları tarafından araştırma nedenlerinin veya bu grupların çevirimiçi ortamda bilgi sağlamasındaki etkenlerin belirlenmesi bakımından faydalı olacağı düşünülmektedir. Bu bağlamda, çalışmanın sanal ortamda hedef tüketici grubuna doğru zamanda, doğru mesajlar vermesi bakımından firma yöneticilerine yol göstermesi beklenmektedir. Çalışmanın araştırmacılara ve yöneticilere tüketiciler arasında çevirimiçi olarak gelişen bilgi paylaşımlarını anlamak ve yönetmek adına yardımcı olacak teorik ve pratik bilgiler sunduğu düşünülmektedir. Çalışma, eAAİ hakkında kavramsal bir çerçeve sunmakla birlikte, eAAİ arama ve sağlama güdülerine ait anahtar değişkenleri tanımlamaktadır. Pazarlama literatüründe eAAİ arama ve sağlama güdülerinin birbiriyle tutarlılık içermeyen, oldukça farklı boyutlar altında işlendiği görülmektedir (Hennig-Thurau vd., 2004; Aydın, 2014; Yildız, 2016; Han, 2008). Bu çalışmada eAAİ arama ve sağlama güdüleri birçok boyut itibariyle incelenerek, bu güdülerin Türk ve yabancı öğrencilere göre farklılıkları tespit edilmiştir.

Çalışma literatüre sunduğu katkının yanı sıra firmalara da çeşitli öneriler sunmaktadır. Firmalara çevrimiçi tüketici topluluklarına aktif olarak katılmaları önerilmektedir. Böylece, firma yöneticileri tüketicilerin ihtiyaç ve isteklerini daha gerçekçi olarak anlayabilir ve aynı zamanda ürün veya hizmet çıktıları ile ilgili geniş çapta bilgi toplayabilirler. Bununla birlikte, pazarlamacılar kararlarında tüketicilerin gitgide çevrimiçi olduklarını, ürün veya hizmet tercihlerinde büyük olasılıkla birçok siteden etkilendiklerini ve bunlara yönelik yorumlara maruz kaldıklarını dikkate almaları gerekmektedir.

Sonuç olarak, tüketicilerin herhangi bir ürün veya hizmeti satın alma karar sürecine etkisi bulunan faktörlere günümüzde sanal ortamlarda dâhil olmuştur. İnternet, tüketicilere çok sayıda tüketicilerle uzun süre etkileşim kurmak adına ek firsatlar sunmaktadır. Bu da tüketicilerin bir ürün/hizmetle ilgili daha fazla bilgiye ulaşmasına ve paylaşımda bulunmasına yol açmaktadır. Dolayısıyla, tüketicilerin çevrimiçi ortamda bilgi arama ve sağlamalarına neden olan güdüleri ve bu güdülerin tüketici gruplarına göre farklılığını ortaya koymanın bu iletişim türünü anlamada katkı sağlayacağı düşünülmektedir.

Gerçekleştirilen bu araştırmanın çeşitli kısıtları bulunmaktadır. Araştırmanın sadece öğrenci grubundan katılımcıların seçilerek gerçekleştirilmesi araştırmanın kısıtlarından birisidir. Ayrıca, yabancı öğrenci gruplarının belirli bir milletten seçilmemesi ve İstanbul'daki yabancı öğrencilerin örneklem çerçevesinde yer alması sonuçların belirli bir etnik gruba mensup öğrenciler üzerinde genelleştirmesini kısıtlamaktadır. Çalışmada eAAİ arama ve sağlama güdüleri belirli boyutları itibariyle ele alınmıştır. Çalışmanın hem eAAİ arama ve sağlama güdülerinin farklı boyutlarının hem de bu boyutların Türk ve yabancı öğrenci gruplarına göre farklılığının ortaya konulması itibariyle literatüre katk1 sağladığı düşünülmektedir.

\section{Kaynakça}

Akehurst, G. (2009). User Generated Content: The Use of Blogs for Tourism Organisations and Tourism Consumers. Service Business, 3(1), 51-61

Akkılıç, E., ve Özbek, E. (2012). İnternet Üzerinden Yapılan Alışverişlerde Ürüne Yönelik Yorumların Tüketici Satın Alma Kararı Üzerindeki Etkisi. Pazarlama ve Pazarlama Araştırmaları Dergisi, 10, 1-14.

Anderson, J. C., \& Gerbing, D. W. (1988). Structural Equation Modeling in Practice: A Review and Recommended Two-Step Approach. Psychological Bulletin, 103(3), 411.

Arndt, J. (1967) Role of Product-Related Conversations in the Diffusion of a New Product. Journal of Marketing Research 4, 291-295.

Arrayo, M. M ve Pandey, T. (2010). Identification of Critical eWOM Dimensions for Music Albums, Proceedings of the 2010 IEEE ICMIT, 1230-1235.

Avcılar, M.Y. (2005). Kişisel Etik Kaynakları ve Ağızdan Ağıza İletişim Ağı, İktisadi ve İdari Bilimler Dergisi, 19(2), 333-347.

Aydın, B. O. (2014). Elektronik Ağızdan Ağıza İletisim: Tüketici Motivasyonlarinin Analizi. Selçuk Üniversitesi Sosyal Bilimler Enstitüsü Dergisi, (32), 13-25.

Brown, M. T., ve Wicker, L. R. (2000). Discriminant Analysis. In Handbook of Applied Multivariate Statistics and Mathematical Modeling, 209-235.

Cheung, C. M., \& Lee, M. K. (2008). Online Consumer Reviews: Does Negative Electronic Word-of-Mouth Hurt More? AMCIS 2008 Proceedings, 143.

Cheung, C. M., \& Thadani, D. R. (2010). The Effectiveness of Electronic Word-of-Mouth Communication: A Literature Analysis. eTrust: Implications for the Individual, Enterprises and Society, In Bled eConference, Slovenia.

Chung, C.M.Y. and Darke, P.R. (2006). The Consumer as Advocate: Self-Relevance, Culture, and Wordof-Mouth, Marketing Letters, 17, 269-279.

Christodoulides, G., Michaelidou, N., \& Argyriou, E. (2012). Cross-National Differences in e-WOM Influence. European Journal of Marketing, 46(11/12), 1689-1707.

Dellarocas, Chrysanthos (2003), The Digitization of Word of Mouth: Promise and Challenges of Online Feedback Mechanisms, Management Science, 49 (10), 1407-1424. 
Ditcher, Ernest (1966), How Word-of-Mouth Advertising Work, Harvard Business, 44 (6), 147- 166.

Demir, S. B. ve Koç, H. (2013). Coğrafya Dersi Tutum Ölçeği: Geliştirilmesi, Geçerlik ve Güvenirlik Çalışması. Turkish Studies-International Periodical for the Languages, Literature and History of Turkish or Turkic 8(8), 1765-1777.

Engel, James F. , Blackwell, Roger D. and Miniard, Paul W. (1993). Consumer Behavior (7th Edition).Texas: Dreyden Press.

Forman. C, A. Ghose, and B.Wiesenfeld (2008). Examining the Relationship Between Reviews and Sales: The Role of Reviewer Identity Disclosure in Electronic Markets, Information Systems Research, 19(3), 291-313.

Godes, David, Dina, Mayzlin, Yubo, Chen, Sanjiv, Das, Chrysanthos Dellarocas and Bruce, Pfeiffer (2005). The Firm's Management of Social İnteractions. Marketing Letters, 16, (3/4), 415-428.

Gruen. T. W., Osmonbekov, T. ve Czaplewski, A. J. (2006). eWOM: The Impact of Customer-to-Customer Online Know-How Exchange on Customer Value and Loyalty, Journal of Business Research, 59(7), 449 456.

Goldsmith, Ronald E. and David Horowitz (2006). Measuring Motivations for Online Opinion Seeking. Journal of Interactive Advertising, 6(2), 1-16.

Han, S. M. (2008). Motivations for Providing and Seeking eWOM: A Cross Cultural Comparison of US and Korean College Students. Michigan State University. Department of Advertising, Michigan.

Hennig-Thurau, Thorsten and Walsh, Gianfranco (2003). Electronic Word-of-Mouth: Motives for and Consequences of Reading Customer Articulations on the Internet. International Journal of Electronic Commerce, 8(2), 51-74.

Hennig-Thurau, Thorsten, Gwinner, Kevin P., Walsh, Gianfranco and Gremler, Dwayne D. (2004). Electronic Word-of-Mouth via Consumer-Opinion Platforms: What Motivates Consumers to Articulate Themselves on the Internet? Journal of Interactive Marketing, 18(1), 38-52.

Jeong, E.; Jang, S.( 2011). Restaurant Experiences Triggering Positive Electronic Word-of-Mouth (eWOM) Motivations. Int. J. Hosp. Management, 30, 356-366

King, R. A., Racherla, P., \& Bush, V. D. (2014). What We Know and Don't Know About Online Word-of-Mouth: A Review and Synthesis of the Literature. Journal of Interactive Marketing, 28(3), 167-183.

Korgaonkar, P. K. and Lori, D. Wolin (1999). A Multivariate Analysis of Web Usage. Journal of Advertising Research, 39(2), 53-68.

Koğar, H. (2010). Farklı Örneklem Büyüklüklerinde Uç Değerlerle Baş Etme Yöntemlerinin Puanların Geçerlik ve Güvenirlik Kanttlarl Üzerindeki Etkisi, Yüksek Lisans Tezi, Ankara Üniversitesi, Eğitim Bilimleri Enstitüsü, Ankara.
Kurtuluş, K. (2010). Araştırma Yöntemleri. İstanbul: Türkmen Kitabevi.

Kwon, J. M., Bae, J-I, \& Phelan, K. (2011). Online Consumer Herding Behaviors in the Hotel Industry Presented at 16th Graduate Students Research Conference, Houston, Texas.

Lam, D., Lee, A., \& Mizerski, R. (2009). The Effects of Cultural Values in Word-of-Mouth Communication. Journal of international Marketing, 17(3), 55-70.

Lerrthaitrakul, W., \& Panjakajornsak, V. (2014). The Impact Of Electronic Word-Of-Mouth Factors on Consumers' Buying Decision-Making Processes in the Low Cost Carriers: A Conceptual Framework. International Journal of Trade, Economics and Finance, 5(2), 142-167

Litvin, S. W., Goldsmith, R. E., \& Pan, B. (2008). Electronic Word-of-Mouth in Hospitality and Tourism Management. Tourism Management, 29(3), 458-468.

Liu, R. R., \& McClure, P. (2001). Recognizing CrossCultural Differences in Consumer Complaint Behavior and Intentions: An Empirical Examination. Journal of Consumer Marketing, 18(1), 54-75.

Oğuzlar, A. (2006). Hanehalkı Tipi ve Kır-Kent Ayırımının Diskriminant Analizi ile İncelenmesi. Akdeniz Üniversitesi Iktisadi Ve Idari Bilimler Fakültesi Dergisi, 6(11), 70-84.

Sarışık, M., ve Özbay, G. (2012). Elektronik Ağızdan Ağıza İletişim ve Turizm Endüstrisindeki Uygulamalara İlişkin Bir Yazın İncelemesi. Yabancı Yönetim İktisat Ve Işletme Dergisi, 8(16), 1-22.

Savić, M., Brcanov, D., \& Dakić, S. (2008). Discriminant Analysis-Applications and Software Support. Management Information Systems, 3(1), 29-33.

Sharma, S. (1996). Applied Multivariate Statistical Analysis. New York, NY: John Wiley \& Sons, Inc.

Shen, W. (2011). Electronic Word-of-Mouth in China: A Motivational Analysis”, E -Business and E Government (ICEE), 2011 International Conference, http://ieeexplore.ieee.org/stamp/stamp.jsp?tp=\&arnumb er=5881777, 6-8 May, 1-6, (Erişim:12.01.2016).

Sundaram, D.S. (1998). Word-of-Mouth Communications: A Motivational Analysis, http://www.acrwebsite.org/volumes/display.asp?id=820 8, (Erişim:25.02.2017).

Sridharan, S. (2016). What Makes One Spread The Word Online-A Study on Electronic Word of Mouth Motivations on Social Networking Sites, Master's thesis, University of Stavanger, Norway.

Sun, T., Youn, S., Wu, G., \& Kuntaraporn, M. (2006). Online Word-of-Mouth (or Mouse): An Exploration of its Antecedents and Consequences. Journal of Computer Mediated Communication, 11(4), 1104-1127.

Thevenot, C. ve Watier, K. (2001). Georgetown University, Communications, Culture \& Technology Program, 
http://www.watier.org/kathy/papers/ViralMarketing.doc (Erișim:02.10.2016).

Thorson, K. S., \& Rodgers, S. (2006). Relationships between Blogs as eWOM and Interactivity, Perceived Interactivity, and Parasocial Interaction. Journal of Interactive Advertising, 6(2), 39-50.

Tsao, W. C., Hsieh, M. T., Shih, L. W., \& Lin, T. M. (2015). Compliance with eWOM: The influence of Hotel Reviews on Booking Intention from the Perspective of Consumer Conformity. International Journal of Hospitality Management, 46, 99-111.

Yalman, N., Ulusu, Y., Sağlık, D., \& Durmuş, B. (2012). Blackberry ve Iphone'un Marka Kişilikleri Farklı Midır?, Pazarlama ve Pazarlama Araştırmaları Dergisi, 10, 83-99.
Yen, C. L. A., \& Tang, C. H. H. (2015). Hotel Attribute Performance, eWOM Motivations, and Media Choice. International Journal of Hospitality Management, 46, 79-88.

Yıldız, E. (2016). Elektronik Ağızdan Ağıza İletişim: Tüketicilerin Elektronik Platformlarda Yorum Yazma Davranışını Etkileyen Faktörler. Gümüshane Üniversitesi Sosyal Bilimler Enstitüsü Elektronik Dergisi, 7(15), 13-25.

Yıldız, S. ve Tehci A. (2014). Ağızdan Ağıza İletişimde Müşteri Tatmini ve Müşteri Sadakati ile Mağaza İmaj1 Boyutları: Ordu İlinde Bir Uygulama, Atatürk Üniversitesi Sosyal Bilimler Enstitüsü Dergisi, 18(1), 441-460. 